Journal of Animal and Veterinary Advances 10 (16): 2090-2094, 2011

ISSN: $1680-5593$

(C) Medwell Journals, 2011

\title{
A Simpler Method for the Efficient and Precise Deletion of Genes in Salmonella sp.
}

\author{
Shi-Zhong Geng, Xin-An Jiao, Zhi-Ming Pan, Qiang Fang, \\ Zhi-Fa Wen and Xiang Chen \\ Jiangsu Key Laboratory of Zoonosis, Yang zhou University, \\ Yangzhou, 225009 Jiangsu, P.R. China
}

\begin{abstract}
A simpler method for the efficient and precise deletion of genes in Salmonella sp. was developed. To demonstrate this approach, the prgH gene of Salmonella typhimurium SL 7207 was deleted by homologous recombination with a temperature-sensitive plasmid containing a cassette that two DNA fragments as homologous arms flanking chloramphenicol resistance gene $\left(\mathrm{Cm}^{R}\right)$ which replaced the prgH gene. During screening mutant at $44^{\circ} \mathrm{C}$, the temperature-sensitive plasmid was lost easily only the mutant which $\mathrm{prgH}$ gene was replaced by $\mathrm{Cm}^{R}$ gene could grow in the LB media with chloramphenicol. The results showed that the method was simpler, more effective to delete target gene in genomic DNA of Salmonell sp. than those conventional methods.
\end{abstract}

Key words: Salmonella, deletion of gene, $\mathrm{prgH}$ gene, homologous recombination, temperature, China

\section{INTRODUCTION}

Allelic exchange experiments allow investigation of the functions of many unknown genes identified during the sequencing of entire genomes (Zhou et al., 2010).

Deleting directed gene is a central technique used to demonstrate gene function in many studies (Zhou et al., 2010). Several main different methods of gene deletions have been reported in Salmonella sp. including use of the R6K-suicide plasmid (Miller and Mekalanos, 1988; Philippe et al., 2004), the $\lambda$-Red disruption system (Kuwayama et al., 2002; Datsenko and Wanner, 2000; Doublet et al., 2008), the suicide plasmid combined with the Red system (Geng et al., 2009) or the plasmid with temperature-sensitive with $S a c B$ gene (pKO3) (Link et al., 1997; Hamann et al., 2005; Hamilton et al., 1989).
Although, these methods were reported many times few of them were applied successfully when we attempted to delete $\operatorname{prgH}$ (Kubori et al., 1998; Kimbrough and Miller, 2000) gene of Salmonella sp. In this study, researchers reported a simpler and precise method to knock out prgH gene of Salmonella sp.

\section{MATERIALS AND METHODS}

Bacteria and plasmids: The strains and plasmids used in this study were shown in Table 1. Strains were grown in rich liquid or solid (12 $\mathrm{g} \mathrm{L}^{-1}$ agar) Luria Broth (LB) medium. The media were supplemented with ampicillin (Amp, $100 \mu \mathrm{g} \mathrm{mL}^{-1}$ ), chloramphenicol $\left(\mathrm{Cm}, 50 \mu \mathrm{gL}^{-1}\right.$ ), streptomycin (Sm, $25 \mu \mathrm{g} \mathrm{mL}{ }^{-1}$ ).

\begin{tabular}{|c|c|c|c|c|}
\hline Parameters & Name & Description & Source & References \\
\hline \multirow[t]{3}{*}{ Strains } & S. typhimurium $\mathrm{SL} 7207\left(\mathrm{Sm}^{\mathrm{R}}\right)$ & Parent & Lab collection & - \\
\hline & E. coli. DH5 $\alpha$ & E. coli for cloning pMD18 & Lab collection & - \\
\hline & E. coli. BW 25113 & E. coli for cloning $\mathrm{pKD} 46$ & CGSC, USA & - \\
\hline \multirow[t]{9}{*}{ Plasmids } & pKD4 & Plasmid containing $\mathrm{Cm}^{\mathrm{R}}$ gene & Dr. Cristina Marolda & Datsenko and Wanner $(2000)$ \\
\hline & pCP20 & Plasmid of expressing FLP & Dr. Cristina Marolda & Datsenko and Wanner (2000) \\
\hline & pKD46 & Plasmid with repA101(ts) & CGSC,USA & Datsenko and Wanner (2000) \\
\hline & pMD18 & Plasmid for cloning & Takara, JP & - \\
\hline & pMD-prgH-u & prgH-u cloned into pMD18 & This work & - \\
\hline & pMD-prgH-d & prgH-d cloned into pMD18 & This work & - \\
\hline & $\mathrm{pMD}-\mathrm{Cm}^{\mathrm{R}}$ & $\mathrm{Cm}^{R}$ gene cloned into pMD18 & This work & - \\
\hline & pMD-prgH-u+d $\left(\mathrm{Cm}^{\mathrm{R}}\right)$ & prgH-u+d $\left(\mathrm{Cm}^{\mathrm{R}}\right)$ cloned into pMD18 & This work & - \\
\hline & pKD46-prgH-u+d $\left(\mathrm{Cm}^{\mathrm{R}}\right)$ & prgH-u+d $\left(\mathrm{Cm}^{\mathrm{R}}\right)$ cloned into pKD46 & This work & - \\
\hline
\end{tabular}

Corresponding Author: Xin-An Jiao, Jiangsu Key Laboratory of Zoonosis, Yangzhou University, 12 East Wenhui Road, Yangzhou, 225009 Jiangsu, P.R. China 
Construction of plasmid pKD46-prgH-u+d $\left(\mathrm{Cm}^{\mathrm{R}}\right)$ for knocking out of $\mathbf{p r g H}$ gene: The plasmid $\mathrm{pKD} 46-\mathrm{prgH}-$ $\mathrm{u}+\mathrm{d}\left(\mathrm{Cm}^{\mathrm{R}}\right)$ was constructed following the process shown in Fig. 1. All of the primers used in this study were shown in Table 2 .

Screening the $\Delta \mathrm{prgH} / \mathrm{Cm}^{\mathrm{R}}$ mutant of $S$. typhimurium SL7207: Plasmid pKD46-prgH-u+d $\left(\mathrm{Cm}^{\mathrm{R}}\right)$ was transformed to S. typhimurium SL 7207 by electroporation instrument and the recombinants (SL7207::pKD46-prgH$\mathrm{u}+\mathrm{d}\left(\mathrm{Cm}^{\mathrm{R}}\right)$ ) with Amp and $\mathrm{Cm}$ resistance were cultured in $28^{\circ} \mathrm{C}$, one colony was cultured in the $\mathrm{LB}$ media with $\mathrm{Cm}$ at $28^{\circ} \mathrm{C}$ and subcultured $(100 \mu \mathrm{L}$ of the culture was used to inoculate $4 \mathrm{~mL}$ of fresh media) for $12 \mathrm{~h}$ at $44^{\circ} \mathrm{C}$ and repeat 8-10 times (Fig. 2). At last, serial dilutions of the culture were prepared and plated $250 \mu \mathrm{L}$ of the $10^{-4}, 10^{-5}$ and $10^{-6}$ dilutions onto LB $(\mathrm{Cm})$ agar plates and incubated for $\sim 16 \mathrm{~h}$ at $44^{\circ} \mathrm{C}$. Each colony screened should be patched on an LB (Cm) agar plate and an LB (Amp) plate. Only those colonies that grew on LB $(\mathrm{Cm})$ plate and did not grow in LB (Amp) plate would be correct. On average 50-100 positive colonies were screened.

The colonies of the $\Delta \mathrm{prgH} / \mathrm{Cm}^{\mathrm{R}}$ mutant that could only grow on the $\mathrm{LB}(\mathrm{Cm})$ plates were furtheridentified by PCR and its characteristics related to prgH gene was verified. The SL7207 $\Delta \mathrm{prgH}$ mutant was received from the $\Delta \mathrm{prgH} / \mathrm{Cm}^{\mathrm{R}}$ mutant by pCP20 plasmid (Fig. 2) (Datsenko and Wanner, 2000; Doublet et al., 2008).

\section{Verification of the SL7207 $\Delta \mathrm{prgH} / \mathrm{Cm}^{\mathrm{R}}$ mutant} PCR identification of SL7207 $\Delta \mathrm{prgH} / \mathrm{Cm}^{\mathrm{R}}$ mutant: Primers asdp5/asdp6 (asdp5 is in the asdp12 sequence and asdp6 is in the asdp34 sequence) were used to further identify the $\Delta \mathrm{prgH} / \mathrm{Cm}^{\mathrm{R}}$ mutant. The stn gene (Geng et al., 2009) was amplified with the primer set $s t n F / s t n R$ (Table 2) which specifically identified Salmonella sp.

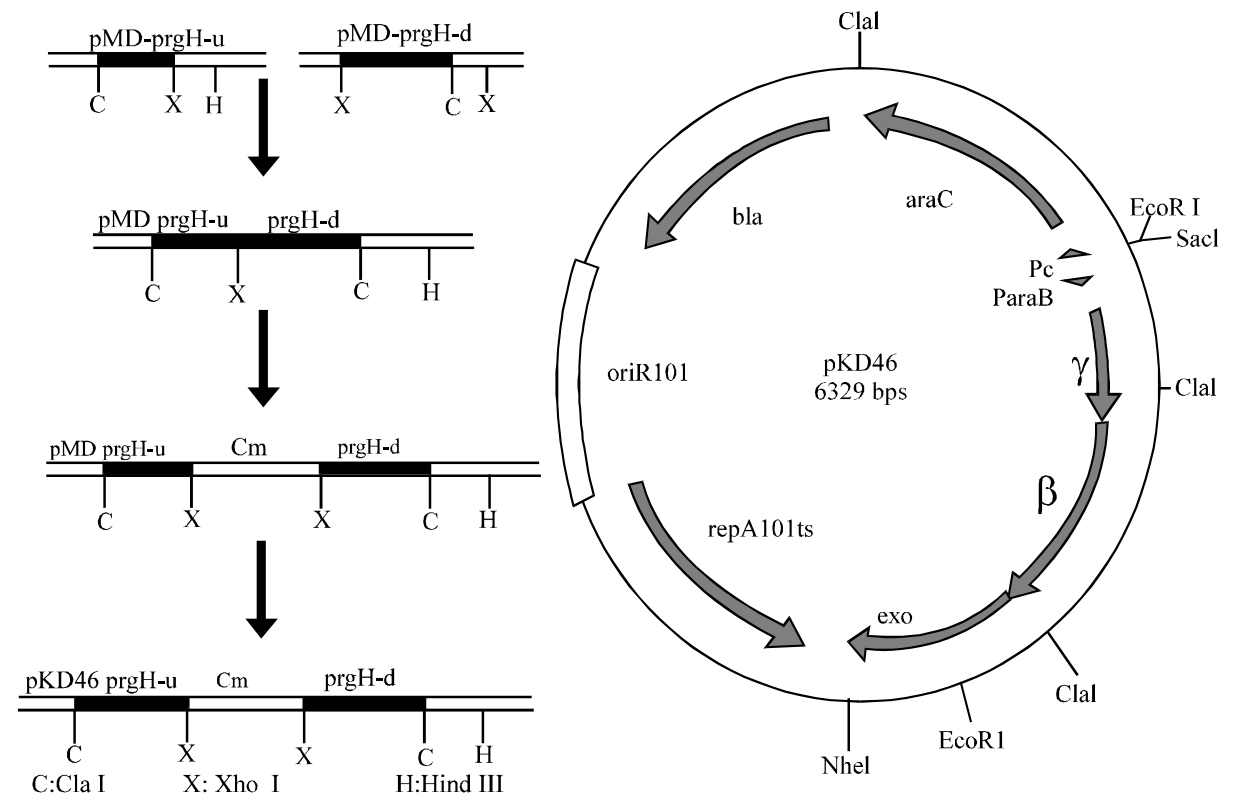

Fig. 1: The construction of plasmid pKD46-prgH- $\mu+d\left(\mathrm{Cm}^{\mathrm{R}}\right)$

\begin{tabular}{|c|c|c|c|c|}
\hline Genes & Primers & Primer sequences $\left(5^{\prime}-3^{\prime}\right)$ & Amplicon size (bp) & Note \\
\hline \multirow[t]{2}{*}{$\overline{p r g H}-U$} & prgH p1 & aaactcgagCGCCATGGTCCAGCGGGATA & 1.164 & Xho I \\
\hline & prgH p 2 & aaagtcgacatcgatTGCCGGCCTTAATCCACAGGG & - & Sal I, Cla I \\
\hline \multirow[t]{2}{*}{$\operatorname{prg} H-D$} & prgH p3 & aaggtcgacatcgat CTGATGCGCAAGCGGCGAAC & 1.749 & Sal I, Cla I \\
\hline & prgH p4 & aaactcgagACTGGCTCAAGGGGCGCTCA & - & Xho I \\
\hline \multirow[t]{2}{*}{ prgH } & prgH p 5 & AGTAGCGCCGGATCGGAGGG & 1.697 (parent) & - \\
\hline & prgH p 6 & TGCGGCAGGACGCTGATGAC & $1.841\left(\Delta \mathrm{prgH}+\mathrm{Cm}^{\mathrm{R}}\right)$ & - \\
\hline \multirow[t]{2}{*}{$\operatorname{prg} H-(R T)$} & prgH-(RT)-F & ACATCATCGAGCGCCCCCTGA & 446 & - \\
\hline & prgH-(RT)-R & GTGTTGCCAGGCCGGGACAAA & - & - \\
\hline \multirow[t]{2}{*}{$C m^{R}$} & $\mathrm{CmF}$ & actcgagGTGTAGGCTGGAGCTGCTTC & 1.032 & Xho I \\
\hline & $\mathrm{CmR}$ & actcgagATGGGAATTAGCCATGGTCC & - & Xho I \\
\hline \multirow[t]{2}{*}{$S t n$} & $\operatorname{stn} F$ & CTTTGGTCGTAAAATAAGGCG & 260 & Salmonella sp. \\
\hline & $\operatorname{stnR}$ & TGCCCAAAGCAGAGAGATTC & - & - \\
\hline
\end{tabular}




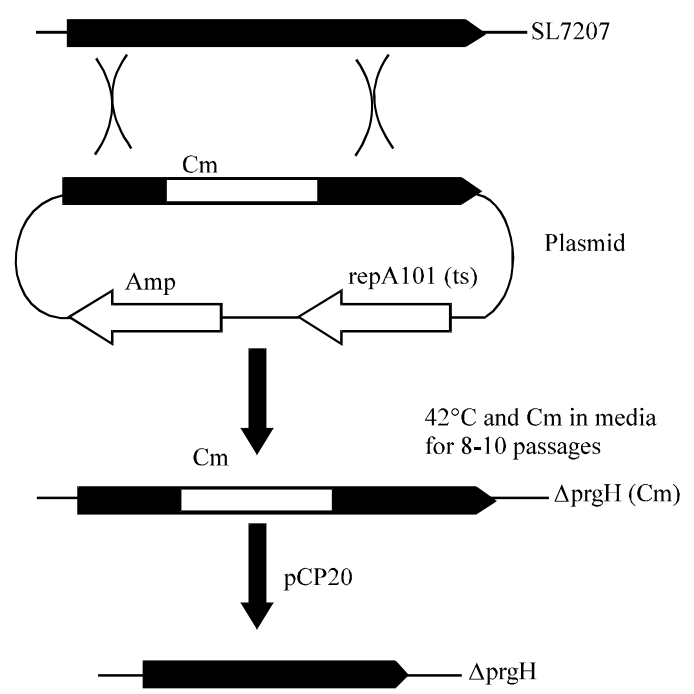

Fig. 2: The screening strategy for the $\Delta \mathrm{prgH}$ mutant

Detecting of mRNA of $p r g H$ gene by Reverse Transcription-PCR (RT-PCR): The SL $7207 \Delta \mathrm{prgH} / \mathrm{Cm}^{\mathrm{R}}$ mutant and parent SL 7207 were cultured and their mRNA were extracted by mRNA extraction Kit of RNAiso Plus respectively, $p r g H$ gene was detected of by RT-PCR to determine whether $\mathrm{prgH}$ gene was expression the primers were shown in Table 2.

Biochemical characteristics: The basic biochemical characteristics of the $\Delta \mathrm{prgH} / \mathrm{Cm}^{\mathrm{R}}$ mutant were evaluated by biochemical tube test.

\section{RESULTS AND DISCUSSION}

PCR identification of $\mathrm{SL} 7207 \Delta \mathrm{prgH} / \mathrm{Cm}^{\mathrm{R}}$ mutant: The PCR products of primer set asdp5/asdp6 showed that bacteria with Plasmid pKD46-prgH-u+d $\left(\mathrm{Cm}^{\mathrm{R}}\right)$ possessed two copies of an upstream fragment and a downstream fragment of the $\operatorname{prgH}$ gene, the SL 7207 had only one copy. After mutant being screened, the $\mathrm{prgH}$ gene was replaced by the $\mathrm{Cm}^{\mathrm{R}}$ gene, the amplicons were 1,697 bp (parent) and 1,697bp and 1,841 bp (the recombinant with Plasmid pKD46-prgH-u+d $\left(\mathrm{Cm}^{\mathrm{R}}\right), 1,841 \mathrm{bp}\left(\Delta \mathrm{prgH} / \mathrm{Cm}^{\mathrm{R}}\right.$ mutant) (Fig. 3). These results indicated that an $\Delta \mathrm{prgH} / \mathrm{Cm}^{\mathrm{R}}$ mutant had been constructed whose genomic DNA lacked the prgH gene. The $s t n$ gene was amplified with the primer set $\operatorname{stnF} / \mathrm{stnR}$, the amplicon size was 260 bp (Fig. 4), the result showed that the mutant was Salmonella sp.

Detecting of mRNA of $p r g H$ gene by reverse transcription-PCR (RT-PCR): The result of RT-PCR showed that SL $7207 \Delta \mathrm{prgH} / \mathrm{Cm}^{\mathrm{R}}$ mutant did not express mRNA of prgH gene as a control, the parent SL 7207 could express mRNA of $\mathrm{prgH}$ gene (Fig. 5). This illustrated

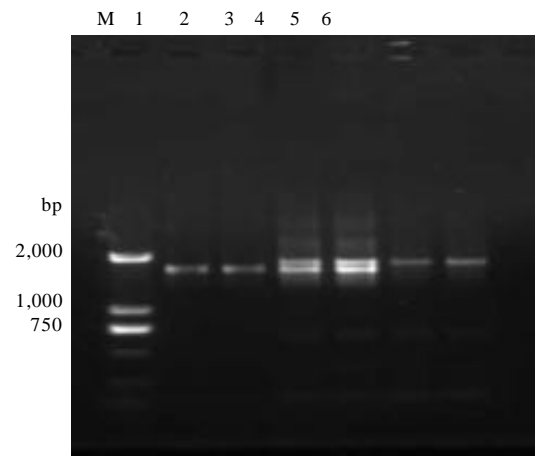

Fig. 3: PCR identification by prgHp5/p6 of SL7207 $\triangle \mathrm{prgH} / \mathrm{Cm}^{\mathrm{R}} \mathrm{M}$ DNA marker DL20001; 2: SL 7207; 3-4: the recombinants; 5: SL7207 $\Delta \mathrm{prgH} / \mathrm{Cm}^{\mathrm{R}}$

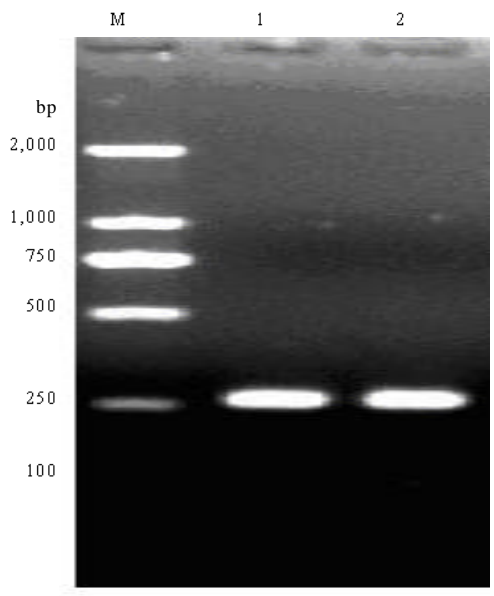

Fig. 4: PCR identification based on stn gene of Salmonella sp. MDNA MarkerDL2000; 1: SL 7207 $\triangle \mathrm{prgH} / \mathrm{Cm}^{\mathrm{R}} ;$ 2: SL 7207

Table 3: Biochemical identification of the SL7207 $\left(\Delta \mathrm{prgH} / \mathrm{Cm}^{\mathrm{R}}\right)$ and parent strain SL 7207

\begin{tabular}{lcc}
\hline Parameters & $\mathrm{SL} 7207\left(\Delta \mathrm{prgH} / \mathrm{Cm}^{\mathrm{R}}\right)$ & SL7207 \\
\hline Glucose & + & + \\
Maltose & + & + \\
Mannose & + & + \\
Sorbitol & - & - \\
Sucrose & - & - \\
Lactose & - & - \\
$\mathrm{H}_{2} \mathrm{~S}$ & + & + \\
Urea & - & - \\
Lysine decarboxylase & + & + \\
KCN & - & - \\
Gelatin & - & - \\
TSI & - & - \\
IMViC & ---+ & ---+ \\
\hline
\end{tabular}

further that the SL $7207 \Delta \mathrm{prgH} / \mathrm{Cm}^{\mathrm{R}}$ mutant did not have the $\mathrm{prgH}$ gene which had been knocked out from genomic DNA of the parent SL 7207.

Biochemical characteristics: The results of biochemical tube test of the mutant were consistent with those of parent SL 7207 (Table 3). The SL $7207\left(\Delta \mathrm{prgH} / \mathrm{Cm}^{\mathrm{R}}\right)$ mutant 
Table 4: The difference of different methods of gene deletions in Salmonella $\mathrm{sp}$.

\begin{tabular}{|c|c|c|c|c|}
\hline \multirow[b]{2}{*}{ Methods } & \multicolumn{4}{|l|}{ The mutant being screened } \\
\hline & Vector & $C m^{R}$ gene & The recombinants of first crossing & Vector lost \\
\hline$\lambda$-Red system & $\begin{array}{l}\text { pKD46, phage } \lambda \text {-Red recombinase } \\
\text { inducted by arabinose (difficult) }\end{array}$ & Mutant with $\mathrm{Cm}^{\mathrm{R}}$ gene & The recombinants with $\mathrm{Cm}^{\mathrm{R}}$ gene & - \\
\hline R6K-Suicide plasmid & pGMB151, $\lambda$-pir protein & No & $\begin{array}{l}\text { Diffcult to get sucrose-sensitive } \\
\text { recombinants and differentiate the } \\
\text { donor and the recipient }\end{array}$ & Sucrose (difficult) \\
\hline $\begin{array}{l}\mathrm{Cm}^{\mathrm{R}} \text { replacement based } \\
\text { on R6K-Suicide plasmid }\end{array}$ & pGMB151, $\lambda$-pir protein & Mutant with $\mathrm{Cm}^{\mathrm{R}}$ gene & $\begin{array}{l}\text { Diffcult to get sucrose-sensitive } \\
\text { recomb inants and easy to differentiate } \\
\text { the donor and the recipient }\end{array}$ & Sucrose (difficult) \\
\hline $\begin{array}{l}\mathrm{Cm}^{\mathrm{R}} \text { replacement based on } \\
\text { temperature-sensitive plasmid }\end{array}$ & pKD46 at $28^{\circ} \mathrm{C}$ & Mutant with $\mathrm{Cm}^{\mathrm{R}}$ gene & the recombinants with $\mathrm{Cm}^{\mathrm{R}}$ gene & $44^{\circ} \mathrm{C}$ (easy) \\
\hline
\end{tabular}

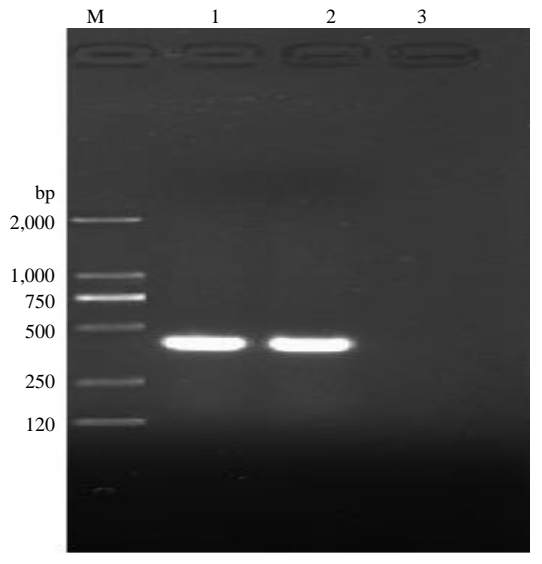

Fig. 5: RT-PCR identification by prgH-(RT) primers M:DNA Marker DL2000; 1: SL 7207; 2: SL 7207; 3: $\mathrm{SL} 7207\left(\Delta \mathrm{prgH} / \mathrm{Cm}^{\mathrm{R}}\right)$

was constructed successfully during 3 weeks using this method based on temperature-sensitive plasmid with RepA101 (ts). Because target gene was replaced by $\mathrm{Cm}^{\mathrm{R}}$ gene in the temperature-sensitive plasmid. At $44^{\circ} \mathrm{C}$, this plasmid was lost easily from the recombinants at the same time, the parent SL7207 had no Cm restance, SL 7207 without pKD46-prgH-u+d $\left(\mathrm{Cm}^{\mathrm{R}}\right)$ was dead in the LB $(\mathrm{Cm})$ media. Only when target gene $(p r g H)$ was replaced by $\mathrm{Cm}^{\mathrm{R}}$ gene via allele replacement and the recombinants [SL 7207::pKD46-prgH-u+d (Cm)] lostplasmid, the mutant with $\mathrm{Cm}^{R}$ gene and without prgH gene could grow in the $\mathrm{Cm}$ and $44^{\circ}$ and could not grow on LB ( Amp) plates. And so, by subculturing 8-10 times, the mutant could be retrieved. Comparing with the Red system (Table 4), the method need not what $\mathrm{pKD} 46$ plasmid was transformated into target bacteria and induced by arabinose to express phage $\lambda$ Red recombinase which was unsure in the try (Datsenko and Wanner, 2000). Although, $\lambda$-Red Disruption system looked simple and was applied in $E$. coli and other G-bacteria, researchers tried many times with Red system in Salmonella sp. but at last failed. As a control, researchers cloned the cassette into the R6K-suicide plasmid with $S a c B$ gene (Geng et al., 2009) and the temperature-sensitive plasmid. In theory, the recombinant bacteria with the $\mathrm{R} 6 \mathrm{~K}$-suicide plasmid was very sensitive to sucrose because levansucrase was expressed by the $S a c B$ gene which was lethal to bacteria in the presence of $10 \%$ sucrose and utilized as a positive and counter-selectable markers in the template plasmid (Gay et al., 1983) but during screening mutant, it is difficult to receive a clony with suicide plasmid which is sensitive to sucrose in spite that we success in knocking out this gene.

\section{CONCLUSION}

In this improved method, some uncertain factors were avoid by temperature-sensitive plasmid replacing R6K-suicide plasmid such as phage $\lambda$ Red recombinase, levansucrase only temperature was used to make plasmid lose and speed process of screening mutant under the $\mathrm{Cm}$ antibiotic which was positive and counter-selectable markers in the mutant. In brief, this method was simpler than the others to generate precise gene deletions in Salmonella sp.

\section{ACKNOWLEDGEMENTS}

The researchers thank sincerely Dr. Cristina Marolda and CGSC (Coli Genetic Stock Center) in USA for their help and guide in gene knock-out and thank the cooperation of faculty members at Jiangsu Key Laboratory of Zoonosis in Yangzhou University. This research was supported by key projects in the National Science and Technology Pillar Program (2009BADB9B01), National Programs for Fundamental Research and Development of China (2006CB504404), National Nature Science Foundation of China (No. 30871860, 30425031) and the Government of Jiangsu Province (Nos. BK200801 1 and BK2010039).

\section{REFERENCES}

Datsenko, K.A. and B.L. Wanner, 2000. One-step inactivation of chromosomal genes in Escherichia coli K-12 using PCR products. Proc. Natl. Acad. Sci. USA., 97: 6640-6645. 
Doublet, B., G. Douard, H. Targant, D. Meunier, J.Y. Madec and A. Cloeckaert, 2008. Antibiotic marker modifications of [lambda] Red and FLP helper plasmids, pKD46 and pCP20, for inactivation of chromosomal genes using PCR products in multidrug-resistant strains. J. Microbiol. Meth., 75: 359-361.

Gay, P., D. Le Coq, M. Steinmetz, E. Ferrari and J.A. Hoch, 1983. Cloning structural gene $\mathrm{SacB}$, which codes for exoenzyme levan-sucrase of Bacillus subtilis: Expression of the gene in Escherichia coli. J. Bacteriol., 153: 1424-1431.

Geng, S.Z., X.A. Jiao, Z.M. Pan, X.J. Chen, X.M. Zhang and $X$. Chen, 2009. An improved method to knock out the asd gene of Salmonella enterica Serovar Pullorum. J. Biomed. Biotechnol., 2009: 646380646380.

Hamann, A., K. Krause, A. Werner and H.D. Osiewacz, 2005. A two-step protocol for efficient deletion of genes in the filamentous ascomycete Podospora anserina. Curr. Genet., 48: 270-275.

Hamilton, C.M., M. Aldea, B.K. Washburn, P. Babitzke and S.R. Kushner, 1989. New method for generating deletions and gene replacements in Escherichia coli. J. Bacteriol., 171: 4617-4622.

Kimbrough, T.G. and S.I. Miller, 2000. Contribution of Salmonella typhimurium type III secretion components to needle complex formation. Proc. Natl. Acad. Sci. USA., 97: 11008-11013.
Kubori, T., Y. Matsushima, D. Nakamura, J. Uralil and M. Lara-Tejero et al., 1998. Supramolecular structure of the Salmonella typhimurium type III protein secretion system. Sci., 280: 602-605.

Kuwayama, H., S. Obara, T. Mario, M. Katoh, H. Urushihara and Y. Tanaka, 2002. PCR-mediated generation of a gene disruption construct without the use of DNA ligase and plasmid vectors. Nucleic Acids Res., 30: E2-E2.

Link, A.J., D. Phillips and G.M. Church, 1997. Methods for generating precise deletions and insertions in the genome of wild-type Escherichia coli: Application to open reading frame characterization. J. Bacteriol., 179: 6228-6237.

Miller, V.L. and J.J. Mekalanos, 1988. A novel suicide vector and its use in construction of insertion mutations: osmoregulation of outer membrane proteins and virulence determinants in Vibrio cholerae requires toxR. J. Bacteriol., 170: 2575-2583.

Philippe, N., J.P. Alcaraz, E. Coursange, J. Geiselmann and D. Schneider, 2004. Improvement of pCVD442, a suicide plasmid for gene allele exchange in bacteria. Plasmid., 51: 246-255.

Zhou, Q.M., D.J. Fan, J.B. Xie, C.P. Liu and J.M. Zhou, 2010. A method for generating precise gene deletions and insertions in Escherichia coli. World J. Microb. Biotech., 26: 1323-1329. 